\title{
PENGARUH KOMPETENSI PEDAGOGIK DAN MANAJEMEN PEMBELAJARAN TERHADAP PENJAMINAN MUTU PADA UNIVERSITAS SANG BUMI RUWA JURAI LAMPUNG
}

\author{
Nurhadi Kusuma1 ${ }^{1}$ Eri Purwanti ${ }^{1(a)}$
}

\begin{abstract}
Quality assurance of education is a concept in education quality management. In the application of this concept any school or educational institution is directed to ensure that the educational services provided meet or exceed the expectations of its customers, both internal and external customers. Internal customers are teachers and school employees, while the primary external customers are learners. The results of this study indicate that pedagogic competence at the University of Bumi Bumi Ruwa Jurai Lampung significant influence on quality assurance that is equal to $59.80 \%$. This is influenced by the purpose of teaching and in making a good, fast, and timely teaching program plan, a high quality assurance is a driver of quality assurance.
\end{abstract}

Keywords: Learning Management, Pedagogic Competency, Quality Assurance.

\section{INDONESIAN JOURNAL OF EDUCATIONAL COUNSELING}

Website: http://ojs.ejournal.id/index.php/ijec

Permalink: http://ojs.ejournal.id/index.php/ijec/article/view/107

How to cite (APA): Kusuma, N., \& Purwanti, E. (2017). Pengaruh kompetensi pedagogik dan manajemen pembelajaran terhadap penjaminan mutu pada Universitas Sang Bumi Ruwa Jurai Lampung. Indonesian Journal of Educational Counseling, 1(2), 209-226.

This is an open access article distributed under the terms of the Creative Commons Attribution 4.0 International License, which permits unrestricted use, distribution, and reproduction in any medium, provided the original work is properly cited.

\section{PENDAHULUAN}

Salah satu bentuk konkrit dalam perbaikan mutu adalah proses pembelajaran. Proses pembelajaran tidak bisa dipisahkan dari peran seorang yang mampu membawa kearah perubahan baik pemikiran maupun tingkah laku. Peran yang dimaksud adalah guru atau dosen. Sardiman (1994) menyebut bahwa peran atau aktivitas guru/dosen adalah mengorganisasi atau mengatur lingkungan sebaik-baiknya dan menghubungkannya dengan anak/peserta didik, sehingga terjadi proses belajar mengajar.

Namun dalam hal ini penulis menfokuskan pada dua aspek pengkajian yaitu kompetensi dan manajemen pembelajaran. Yang mana kedua hal tersebut sangat bersentuhan langsung dengan guru dan peserta didik serta proses

\footnotetext{
${ }^{1}$ Sekolah Tinggi Ilmu Tarbiyah (STIT) Pringsewu, Lampung.

a eripurwantimpd@gmail.com.
} 
pembelajaran. yang mana akan mengarah pada terjaminnya kualitas pendidikan dan pencapaian tujuan pendidikan nasional.

Kompetensi yang dimaksudkan adalah sesuai pada UU Guru dan Dosen NO 14 Tahun 2005 Pasal 10 yang berbunyi "Kompetensi guru sebagai mana dimaksud adalah kompetensi pedagogik, kompetensi sosial, kompetensi kepribadian, dan kompetensi profesional yang diperoleh melalui pendidikan profesi".

Kompetensi pedagogik dan manajemen pembelajaran yang dimaksudkan adalah bagaimana seorang guru ataupun dosen memiliki kapasitas keahlian yang sesuai dengan apa yang diajarkan serta bagaimana seorang guru atau dosen mampu menyampaikan materi yang diajarkan sesuai dengan yang direncanakan sesuai keahlian dan materi pembelajaran yang diampunya, seperti menyusun silabus, membuat perangkat pembelajaran, menguasai metodhe dan strategi pembelajaran, menguasai media pembelajaran, yang pada intinya bagaimana seorang guru atau dosen mampu menguasai kelas sehingga tercapai tujuan pembelajaran yang di inginkan.

Perguruan tinggi yang dianggap mampu mencetak insan yang berdaya guna tidak terlepas dari peran dosen-dosen yang profesional, namun tidak sedikit dosen yang mengajar belum sesuai dengan kompetensinya dan menerapkan perangkat atau manajemen pembelajaran yang baik, hal ini berpengaruh pada output lulusan yang dihasilkan pada suatu perguruan tinggi. Gelar akademik yang tinggi bukan menjadi jaminan bagi seorang dosen untuk menguasai kompetensi pedagogik maupun manajemen pembelajaran.

Berdasarkan latar belakang di atas, maka penelitian ini bertujuan mengkaji pengaruh kompetensi pedagogik dan manajemen pembelajaran dosen terhadap penjaminan mutu pada program pasca sarjana magister manajemen Universitas Sang Bumi Ruwa Jurai. Universitas Sang Bumi Ruwa Jurai (USBRJ) yang berlokasi di Jl. Imam Bonjol 468, Kelurahan Langkapura, Kecamatan Kemiling, Bandar Lampung, Lampung, merupakan salah satu perguruan tinggi swasta tertua di lampung, terhitung sudah meluluskan 1124 orang terhitung dari tahun 2001 sampai 2004 (Data situs resmi UNISAB). Pada tahun 2008, USBRJ membuka program pasca sarjana (S2), dengan program Magister Manajemen.

\section{METODE}

Penelitian ini menggunakan tiga hirarki, yaitu tahap satu, tahap dua, dan tahap tiga. Tahap pertama adalah menentukan hubungan antara kompetensi pedagogik dan manajemen pembelajaran yang terdiri dari dua variable bebas 
$\left(\mathrm{X}^{1}, \mathrm{X}^{2}\right)$. Pada tahap kedua menentukan pengaruh variabel kompetensi pedagogic dan manajemen pembelajaran terhadap penjaminan mutu internal yang dikategorikan sebagai variabel terikat $(\mathrm{Y})$. Pada tahap ketiga adalah pengujian hipotesis yang di dasari pada adanya hubungan antara variabel $X^{1}$ dan $X^{2}$, dalam hal ini adalah kompetensi pedagogic dan manajemen pembelajaran, dan pengaruhnya terhadap variabel $\mathrm{Y}$, dalam hal ini penjaminan mutu internal.

Indikator pengukuran dalam penelitian ini adalah dengan menggunakan skala likert (Cooper \& Emory, 1995: 194). Faktor-faktor yang dianggap dapat mewakili kriteria pengukuran variabel tersebut diberi nilai atau skor. Skala licert ini digunakan untuk mengetahui bagai mana Dosen dalam mengajar. Penelitian ini menggunakan metode pengumpulan data, yaitu observasi dan angket.

Oservasi dilakukan dengan mengamati dan mencatat kondisi yang ditemukan di lingkungan pasca sarjana USBRJ, untuk mengetahui sejauh mana proses pembelajaran dan pola penjaminan mutu yang ada di lingkungan USBRJ secara umumnya. Angket disebar pada mahasiswa untuk mengetahui persepsi mahasiswa terkait proses pembelajaran. Jumlah mahasiswa yang dijadikan sampel adalah sebanyak 50 orang dengan system acak pada masing-masing angkatan, dengan jumlah soal sebanyak 30 item pertanyaan. Dan dalam penelitian ini penulis membatasi sampel diambil angkatan ke IV, dengan jumlah mahasiswa sebanyak 174 orang.

Sampel diambil secara purpose, dengan cara memilih sekelompok subjek penelitian berdasarkan ciri-ciri atau sifat populasi. Populasi penelitian ini adalah mahasiswa dan dosen pasca sarjana program magister manajemen , yang dipilah dalam dua kelompok.

Kelompok pertama, penetapan sampel secara keseluruhan dari populasi yaitu seluruh dosen program pasca sarjana Universitas Sang Bumi Ruwa Jurai yang berjumlah 30 orang.

Dalam kelompok kedua ini penulis menetapkan sampel pada mahasiswa program Pasca Sarjana Universitas Sang Bumi Ruwa Jurai mengambil 5-10 setiap angkatanya untuk dijadikan sampel. Sedangkan angkatan yang penulis pilih adalah angkatan IV. Yang keseluruhan sampel untuk kelompok kedua adalah sebanyak 50 orang.

Pengujian hipotesis menggunakan korelasi product moment (koefisien korelasi) dan dilanjutkan dengan regresi linier berganda, dengan rumus:

$$
\operatorname{Ryx} 1 \times 2=\frac{r^{2} y x 1+y x^{2}-2 r y x^{1} r y x^{2} r x^{1} x^{2}}{1-r^{2} x^{1} x^{2}}
$$


Dimana:

Ry $\mathrm{x}^{1} \mathrm{X}^{2}=$ Korelasi antara variabel $\mathrm{X}^{1}$ dengan $\mathrm{X}^{2}$ secara bersama -sama dengan variabel $Y$

Ry $\mathrm{x}^{2}=$ Korelasi product moment antara $\mathrm{X}^{1}$ dengan $\mathrm{Y}$

Ry $x^{2}=$ Korelasi product moment $X^{2}$ dengan $Y$

$R x^{1} X^{2}=$ Korelasi product moment antara $X^{1}$ dengan $X^{2}$

Untuk menguji signifikansinya dalam pengujian hipotesis penulis juga menetapkan rumus sebagai berikut:

$$
\begin{gathered}
\mathrm{Fh}=\underline{\mathrm{R}^{2} / \mathrm{k}} \\
\left(1-\mathrm{R}^{2}\right) /(\mathrm{n}-\mathrm{k}-1)
\end{gathered}
$$

Dimana:

$\mathrm{R}=$ koefesien korelasi ganda

$\mathrm{k}=$ jumlah variabel independent

$\mathrm{n}=$ jumlah sampel

\section{HASIL DAN PEMBAHASAN}

\section{Uji Validitas dan Reliabilitas Kompetensi pedagogik}

Pengujian Validitas dan Reliabilitas menggunakan alat bantu program computer (SPSS). Kriterianya adalah instrumen valid apabila nilai korelasi (pearson correlation) adalah positif, dan nilai probabilitas korelasi [sig. (2tailed)] taraf signifikan $(\mathrm{x}$ ) sebesar 0,05 . Kriteria data reliabel adalah apabila instrumen memiliki tingkat reliabilitas yang tinggi jika nilai koefisien yang diperoleh > 0,60 (Ghozali, 2002:133).

Uji validitas kompetensi pedagogik dilakukan untuk mengetahui tingkat kevalidan atau kesahihan suatu instrumen kompetensi pedagogik. Dan hasil output SPSS menghasilkan koefisien untuk mengukur validitas seperti tercantum pada Tabel 1.

Uji Reliabilitas Variabel kompetensi pedagogik dilakukan untuk mengukur keterandalan atau konsistensi instrumen penelitian, dikatakan reliable bila dan instrumen yang sama (tes dengan tes ulang) akan memberikan hasil yang sama, dengan hasil uji tertera pada Tabel 2. 
Pengaruh Kompetensi Pedagogik dan Manajemen Pembelajaran Terhadap

Penjaminan Mutu pada Universitas Sang Bumi Ruwa Jurai Lampung

Tabel 1. Uji Validitas Variabel Kompetensi Pedagogik

\begin{tabular}{|c|c|c|c|c|}
\hline & & Jml & Alpha & Validitas \\
\hline \multirow[t]{2}{*}{$\mathrm{P} 1$} & Pearson Correlation & $.831^{* *}$ & & \\
\hline & Sig.(2-tailed) & $\begin{array}{r}.000 \\
25\end{array}$ & 0,05 & Valid \\
\hline \multirow[t]{3}{*}{ P2 } & Pearson Correlation & $.730^{*}$ & & \\
\hline & Sig.(2-tailed) & .000 & 0,05 & Valid \\
\hline & $\mathrm{N}$ & 25 & & \\
\hline \multirow[t]{3}{*}{ P3 } & Pearson Correlation & $.829^{*}$ & & \\
\hline & Sig.(2-tailed) & .000 & 0,05 & Valid \\
\hline & $\mathrm{N}$ & 25 & & \\
\hline \multirow[t]{3}{*}{ P4 } & Pearson Correlation & $.851^{\star *}$ & & \\
\hline & Sig.(2-tailed) & .000 & 0,05 & Valid \\
\hline & $\mathrm{N}$ & 25 & & \\
\hline \multirow[t]{3}{*}{ P5 } & Pearson Correlation & $.652^{*}$ & & \\
\hline & Sig.(2-tailed) & .000 & 0,05 & Valid \\
\hline & $\mathrm{N}$ & 25 & & \\
\hline \multirow[t]{3}{*}{ P6 } & Pearson Correlation & $.831^{\star *}$ & & \\
\hline & Sig.(2-tailed) & .000 & 0,05 & Valid \\
\hline & $\mathrm{N}$ & 25 & & \\
\hline \multirow[t]{3}{*}{ P7 } & Pearson Correlation & $.720^{\star}$ & & \\
\hline & Sig.(2-tailed) & .000 & 0,05 & Valid \\
\hline & $\mathrm{N}$ & 25 & & \\
\hline \multirow[t]{3}{*}{ P8 } & Pearson Correlation & $.838^{\star \star}$ & & \\
\hline & Sig.(2-tailed) & .000 & 0,05 & Valid \\
\hline & $\mathrm{N}$ & 25 & & \\
\hline \multirow[t]{3}{*}{ P9 } & Pearson Correlation & $.543^{\star}$ & & \\
\hline & Sig.(2-tailed) & .001 & 0,05 & Valid \\
\hline & $\mathrm{N}$ & 25 & & \\
\hline \multirow[t]{3}{*}{$\mathrm{P} 10$} & Pearson Correlation & $687^{*}$ & & \\
\hline & Sig.(2-tailed) & .000 & 0,05 & Valid \\
\hline & $\mathrm{N}$ & 25 & & \\
\hline \multirow{3}{*}{ Jumlah } & Pearson Correlation & 1 & \multirow{3}{*}{0,05} & \multirow{3}{*}{ Valid } \\
\hline & Sig.(2-tailed) & & & \\
\hline & $\mathrm{N}$ & 25 & & \\
\hline
\end{tabular}

${ }^{* *}$ Correlation is significant at the 0.01 level (2-tailed)

${ }^{*}$ Correlation is significant at the 0.05 level (2-tailed)

Tabel 2. Uji Reliabilitas Variabel Kompetensi Pedagogik

Reliability Statistic

\begin{tabular}{rrr}
\hline Cronbach's Alpha & N of Items & \\
\hline .908 & & 10 \\
\hline
\end{tabular}

Dari hasil uji validitas data (Tabel 1) menunjukkan bahwa semua item pernyataan tentang kompetensi pedagogik mempunyai kriteria yang valid. Koefisien Reliabilitas 0,908 > 0,60 (Tabel 2) maka data hasil angket tentang 
kompetensi pedagogik memiliki tingkat reliabilitas yang baik, atau dengan kata lain data hasil angket dapat dipercaya.

\section{Uji Validitas dan Reliabilitas Variabel Penjamin mutu}

Uji validitas Variabel Penjamin mutu dilakukan untuk mengetahui tingkat kevalidan atau kesahihan suatu instrumen Penjamin mutu. Hasil output SPSS menghasilkan koefisien untuk mengukur validitas seperti tertera pada Tabel 3.

Tabel 3. Uji validitas variabel Penjamin Mutu

\section{Correlation}

\begin{tabular}{|c|c|c|c|c|}
\hline & & $\mathrm{Jml}$ & Alpha & Validitas \\
\hline \multirow[t]{3}{*}{ P1 } & Pearson Correlation & $.830^{\star *}$ & & \\
\hline & Sig.(2-tailed) & .000 & 0,05 & Valid \\
\hline & $\mathrm{N}$ & 25 & & \\
\hline \multirow[t]{3}{*}{ P2 } & Pearson Correlation & $826\left(^{* \star}\right)$ & & \\
\hline & Sig.(2-tailed) & .000 & 0,05 & Valid \\
\hline & $\mathrm{N}$ & 25 & & \\
\hline \multirow[t]{3}{*}{ P3 } & Pearson Correlation & $.681\left(^{*}\right)$ & & \\
\hline & Sig.(2-tailed) & .000 & 0,05 & Valid \\
\hline & $\mathrm{N}$ & 25 & & \\
\hline \multirow[t]{3}{*}{ P4 } & Pearson Correlation & $.814\left({ }^{* \star}\right)$ & & \\
\hline & Sig.(2-tailed) & .000 & 0,05 & Valid \\
\hline & $\mathrm{N}$ & 25 & & \\
\hline \multirow[t]{3}{*}{ P5 } & Pearson Correlation & $.628\left(^{*}\right)$ & & \\
\hline & Sig.(2-tailed) & .000 & 0,05 & Valid \\
\hline & Pearson Correlation & $\left..7866^{* \star}\right)$ & & \\
\hline \multirow{2}{*}{ P6 } & Sia. (2-tailed) & 000 & 0.05 & Valid \\
\hline & $\mathrm{N}$ & 25 & & \\
\hline \multirow[t]{3}{*}{ P7 } & Pearson Correlation & $\left..7933^{* \star}\right)$ & & \\
\hline & Sig.(2-tailed) & .000 & 0,05 & Valid \\
\hline & $\mathrm{N}$ & 25 & & \\
\hline \multirow[t]{3}{*}{ P8 } & Pearson Correlation & $.575\left(^{*}\right)$ & & \\
\hline & Sig.(2-tailed) & .000 & 0,05 & Valid \\
\hline & $\mathrm{N}-\mathrm{s}$ & 25 & & \\
\hline \multirow[t]{3}{*}{ P9 } & Pearson Correlation & $.763\left(^{* \star}\right)$ & & \\
\hline & Sig.(2-tailed) & .000 & 0,05 & Valid \\
\hline & $\mathrm{N}$ & 25 & & \\
\hline \multirow[t]{3}{*}{ P10 } & Pearson Correlation & 1 & & \\
\hline & Sig.(2-tailed) & & 0,05 & Valid \\
\hline & $\mathrm{N}$ & 25 & & \\
\hline \multirow{3}{*}{ Jumlah } & Pearson Correlation & $828^{* *}$ & & \\
\hline & Sig.(2-tailed) & 240 & 0,05 & Valid \\
\hline & $\mathrm{N}$ & 25 & & \\
\hline
\end{tabular}

** Correlation is significant at the 0.01 level (2-tailed)

${ }^{*}$ Correlation is significant at the 0.05 level (2-tailed) 
Uji reliabilitas variabel penjamin mutu dilakukan untuk mengukur keterandalan atau konsistensi instrumen penelitian, dikatakan reliable bila dan instrumen yang sama (tes dengan tes ulang) akan memberikan hasil yang sama, dengan hasil uji seperti tertera pada Tabel 4.

Tabel 4. Uji validitas variabel Penjamin Mutu

\begin{tabular}{|c|c|c|c|c|}
\hline & & $\mathrm{Jml}$ & Alpha & Validitas \\
\hline \multirow[t]{2}{*}{ P1 } & Pearson Correlation & $.813^{* *}$ & & \\
\hline & Sig.(2-tailed) & $\begin{array}{r}.000 \\
25\end{array}$ & 0,05 & Valid \\
\hline \multirow[t]{2}{*}{ P2 } & Pearson Correlation & $828\left(^{* *}\right)$ & & \\
\hline & $\begin{array}{l}\text { Sig.(2-tailed) } \\
N\end{array}$ & $\begin{array}{r}.000 \\
25\end{array}$ & 0,05 & Valid \\
\hline \multirow[t]{2}{*}{ P3 } & Pearson Correlation & $.652\left(^{*}\right)$ & & \\
\hline & $\begin{array}{l}\text { Sig.(2-tailed) } \\
N\end{array}$ & $\begin{array}{r}.000 \\
25\end{array}$ & 0,05 & Valid \\
\hline \multirow[t]{2}{*}{ P4 } & Pearson Correlation & $\left..8411^{* *}\right)$ & & \\
\hline & $\begin{array}{l}\text { Sig.(2-tailed) } \\
\mathrm{N}\end{array}$ & $\begin{array}{r}.000 \\
25\end{array}$ & 0,05 & Valid \\
\hline \multirow[t]{2}{*}{ P5 } & Pearson Correlation & $.687\left(^{*}\right)$ & & \\
\hline & $\begin{array}{l}\text { Sig.(2-tailed) } \\
N\end{array}$ & $\begin{array}{r}.000 \\
25\end{array}$ & 0,05 & Valid \\
\hline \multirow[t]{2}{*}{ P6 } & Pearson Correlation & $\left..753^{(* *}\right)$ & & \\
\hline & $\begin{array}{l}\text { Sig.(2-tailed) } \\
N\end{array}$ & $\begin{array}{r}.000 \\
25\end{array}$ & 0,05 & Valid \\
\hline \multirow[t]{2}{*}{ P7 } & Pearson Correlation & $\left..703^{(* *}\right)$ & & \\
\hline & Sig.(2-tailed) & $\begin{array}{r}.000 \\
25\end{array}$ & 0,05 & Valid \\
\hline \multirow[t]{2}{*}{ P8 } & Pearson Correlation & $.582\left(^{*}\right)$ & & \\
\hline & Sig.(2-tailed) & .000 & 0,05 & Valid \\
\hline \multirow[t]{2}{*}{ P9 } & Pearson Correlation & $\left..776^{(* *}\right)$ & & \\
\hline & $\begin{array}{l}\text { Sig.(2-tailed) } \\
N\end{array}$ & $\begin{array}{r}.000 \\
25\end{array}$ & 0,05 & Valid \\
\hline \multirow[t]{2}{*}{ P10 } & Pearson Correlation & 1 & & \\
\hline & $\begin{array}{l}\text { Sig.(2-tailed) } \\
N\end{array}$ & 25 & 0,05 & Valid \\
\hline \multirow[b]{2}{*}{ Jumlah } & Pearson Correlation & $828^{* *}$ & & \\
\hline & $\begin{array}{l}\text { Sig.(2-tailed) } \\
N\end{array}$ & $\begin{array}{r}240 \\
25\end{array}$ & 0,05 & Valid \\
\hline
\end{tabular}

** Correlation is significant at the 0.01 level (2-tailed)

* Correlation is significant at the 0.05 level (2-tailed)

Uji reliabilitas variabel penjamin mutu dilakukan untuk mengukur keterandalan atau konsistensi instrumen penelitian, dikatakan reliable bila dan instrumen yang sama (tes dengan tes ulang) akan memberikan hasil yang sama, dengan hasil uji seperti tertera pada Tabel 5. 
Tabel 5 . Uji reliabilitas Variabel Penjamin Mutu

Reliability Statistic

\begin{tabular}{rr}
\hline Cronbach's Alpha & $\mathrm{N}$ of Items \\
\hline .907 & 10 \\
\hline
\end{tabular}

Dari hasil uji validitas data (Tabel 4) menunjukkan bahwa semua item pernyataan tentang Penjamin mutu mempunyai kriteria yang valid. Reliabilitas 0,907 > 0,60 (Tabel 5) maka hasil data hasil angket tentang Penjamin mutu memiliki tingkat reliabilitas yang baik, atau dengan kata lain data hasil angket dapat dipercaya.

Hasil Penelitian Kompetensi Pedagogik dan Manajemen Pembelajaran

Hasil penelitian diperoleh melalui rekapitulasi jawaban responden yang dianalisis dengan alat analisis korelasi dan regresi linier sederhana menggunakan program SPSS Versi 16.0 yang menghasilkan analisis tabel dan setiap variabel yang melipuiti variabel terikat (dependent variable) yaitu Penjamin mutu $(Y)$, variabel bebas (Independent variable) yaitu Kompetensi pedagogik dan manajemen pembelajaran $\left(\mathrm{X}^{1}\right.$ dan $\left.\mathrm{X}^{2}\right)$ dengan analisis korelasi serta uji hipotesis.

a) Kompetensi pedagogik

Berdasarkan pengolahan data terhadap jawaban responden tentang kompetensi pedagogik dan output SPSS Versi 16.0, maka kriteria variabel media kaset diperoleh seperti tertera pada Tabel 6.

Tabel 6. Distribusi Frekuensi Jawaban Responden Tentang Kompetensi Pedagogik

\begin{tabular}{lccc}
\hline \multicolumn{1}{r}{ Kategori } & Interval & Frekuensi & Persentase \\
\hline Sangat Baik & $43,00-50,00$ & 0 & 0 \\
\hline Baik & $35,00-42,00$ & 18 & 75,00 \\
\hline Sedang & $27,00-34,00$ & 5 & 20,83 \\
\hline Kurang Baik & $18,00-26,00$ & 2 & 4,17 \\
\hline Tidak Baik & $10,00-17,00$ & 0 & 0 \\
\hline Jumlah & & 25 & 100
\end{tabular}

Sumber: Data diolah dari frekuensi output SPSS

Berdasarkan Tabel 6, diperoleh jawaban 18 responden (75,00\%) penggunaan kompetensi pedagogik dalam kriteria baik dan sebanyak 5 responden $(20,83 \%)$ menilal bahwa kompetensi pedagogik dalam kriteria sedang dan terdapat 1 responden $(4,17 \%)$ memberikan tanggapan kompetensi pedagogik dengan kriteria kurang baik dan pada histogram terlihat rata-rata (Mean) sebesar 35,32 dan standar deviasi 3,735. 
Penyajian data kompetensi pedagogik dalam bentuk histogram dan kurva normal tertera pada Gambar 1.

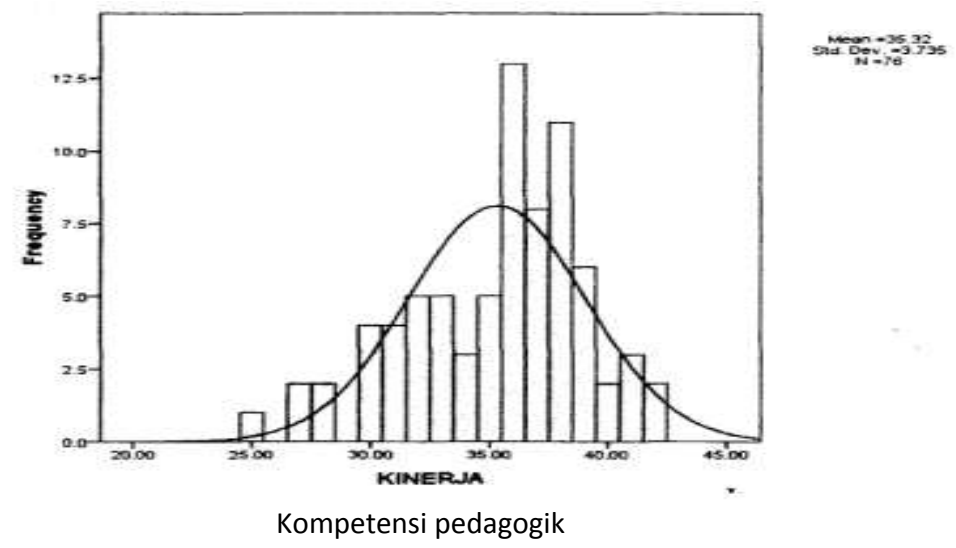

Gambar 1. Histogram dan Kurva Normal Kompetensi Pedagogik

Analisis per indikator/item pernyataan tentang kompetensi pedagogik terlebih dahulu dengan menentukan interval score sebagai berikut:

Total Score Tertinggi $=24 \times 5=120$

Total Score Terendah $=24 \times 1=24$

$I=\frac{N T-N R}{K}$

$I=\frac{240-24}{5}=43,2$

Sehingga diperoleh interval skor sebagai berikut:

$24-66,2$ Tidak Baik

67,2 - 110,2 Kurang Baik

111,2 - 154,2 Sedang

155,2 - 198,2 Baik

193,2 - $240 \quad$ Sangat Baik

Kompetensi pedagogik yang dilaksanakan pada Universitas Sang Bumi Ruwa Jurai dinilai oleh responden dengan rata-rata skor 197,32, seperti ditunjukkan pada Tabel 7. 
Tabel 7. Tabel Profil Kriteria Kompetensi Pedagogik per Indikator/Item Pernyataan

\begin{tabular}{clcc}
\hline No & \multicolumn{1}{c}{ Pernyataan } & Skor Total & Kriteria \\
\hline 1 & $\begin{array}{l}\text { Dalam pembelajaran apakah dosen melakukan } \\
\text { apersepsi sebelum pembelajaran dimulai }\end{array}$ & 150,6 & Sedang \\
\hline 2 & $\begin{array}{l}\text { Apakah dosen merumuskan tujuan secara } \\
\text { realistik dan jelas }\end{array}$ & 198,5 & Baik \\
\hline 3 & $\begin{array}{l}\text { Apakah dosen memulai pembelajaran dengan } \\
\text { menjajaki kemampuan mahasiswa terlebih } \\
\text { dahulu }\end{array}$ & 200,5 & Baik \\
\hline 4 & $\begin{array}{l}\text { Apakah dosen mengintegrasikan life skil dalam } \\
\text { pembelajarannya }\end{array}$ & 195,8 & Baik \\
\hline 5 & $\begin{array}{l}\text { Apakah dosen dalam menyampaikan materi } \\
\text { pembelajaran secara menarik dan mudah } \\
\text { dipahami mahasiswa }\end{array}$ & 199,4 & Baik \\
\hline 6 & $\begin{array}{l}\text { Apakah dosen dalam menjawab pertanyaan } \\
\text { mahasiswa sesuai dengan substansi materi } \\
\text { pembelajaran }\end{array}$ & 235,4 & Baik \\
\hline 7 & $\begin{array}{l}\text { Apakah dosen memberikan kesempatan yang } \\
\text { laus pada mahasiswa untuk mengemukakan } \\
\text { gagasan secara luas }\end{array}$ & 225,2 & Baik \\
\hline 8 & $\begin{array}{l}\text { Apakah dosen memberlakukan metode } \\
\text { pembelajaran yang bervariasi }\end{array}$ & 142,5 & Sedang \\
\hline 9 & $\begin{array}{l}\text { Apakah dosen menjabarkan kurikulum menjadi } \\
\text { program lebih rinci }\end{array}$ & 220,8 & Baik \\
\hline 10 & $\begin{array}{l}\text { Apakah dosen tepat waktu dalam memulai dan } \\
\text { mengakhiri pembelajaran }\end{array}$ & 204,5 & Baik \\
\hline Sumber: Diolah darihasil olah data SPSS 16.0 & & \\
\hline
\end{tabular}

Sumber: Diolah dari hasil olah data SPSS 16.0

b) Manajemen pembelajaran

Berdasarkan pengolahan data dari jawaban responden tentang manajemen pembelajaran dan output SPSS Versi 16. maka kriteria variabel manajemen pembelajaran tertera pada tabel 8.

Tabel 8. Distribusi Frekuensi Jawaban Responden Tentang Manajemen Pembelajaran

\begin{tabular}{lccc}
\hline \multicolumn{1}{c}{ Kategori } & Interval & Frekuensi & Persentase \\
\hline Sangat Baik & $43,00-50,00$ & 1 & 4,16 \\
\hline Baik & $35,00-42,00$ & 16 & 66,67 \\
\hline Sedang & $27,00-34,00$ & 5 & 20,83 \\
\hline Kurang Baik & $18,00-26,00$ & 3 & 8,34 \\
\hline Tidak Baik & $10,00-17,00$ & 0 & 0 \\
\hline Jumlah & & 25 & 100
\end{tabular}

Sumber: Data diolah dari Frekuensi output SPSS 


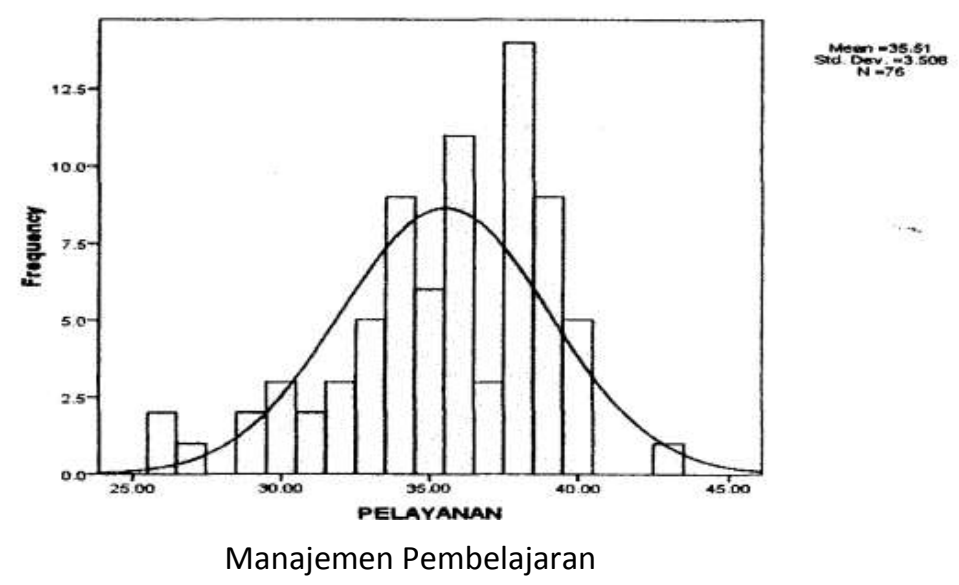

Gambar 2. Histogram dan Kurva Normal manajemen pembelajaran

Berdasarkan Tabel 8, diperoleh jawaban 1 responden (4,16\%) manajamen pembelajaran dalam kriteria sangat baik dan sebanyak 16 responden $(66,67 \%)$ menilai bahwa manajemen pembelajaran dalam kriteria baik dan tedapat 5 responden $(20,83 \%)$ memberikan tanggapan manajemen pembelajaran dengan kriteria sedang dan terdapat 2 responden (8,34\%) memberikan tanggapan manajemen pembelajaran dengan kriteria tidak baik, dan pada histogram terlihat rata-rata (Mean) score 35,51 dan standar deviasi 3,508.

Selanjutnya dapat digambarkan profil manajemen pembelajaran per indikatornya/ item pernyataan dengan terlihat dahulu dengan menentukan interval score sebagai berikut:

Total Score Tertinggi $=24 \times 5=120$

Total Score Terendah $=24 \times 1=25$

$\mathrm{I}=\frac{\mathrm{NT}-\mathrm{NR}}{\mathrm{K}}$

$I=\frac{240-25}{5}=43,2$

Sehingga diperoleh interval skor sebagai berikut:

$24-66,2$ Tidak Baik

67,2 - 110,2 Kurang Baik

$111,2-154,2$ Sedang

155,2 - 198,2 Baik

193,2 - $240 \quad$ Sangat Baik 
Tabel 9. Tabel Profil manajemen pembelajaran per Indikator/ltem Pernyataan

\begin{tabular}{clcc}
\hline No & \multicolumn{1}{c}{ Pernyataan } & Skor Total & Kriteria \\
\hline 1 & $\begin{array}{l}\text { Apakah dosen melaksanakan strategi dan cara } \\
\text { pengelolaan kelas }\end{array}$ & 194,5 & Baik \\
\hline 2 & $\begin{array}{l}\text { Apakah dosen menjaga motivasi dan semangat } \\
\text { mahasiswa dalam proses pembelajaran }\end{array}$ & 235,5 & Baik \\
\hline 3 & $\begin{array}{l}\text { Apakah dosen melakukan evaluasi rencana dan } \\
\text { pelaksanaan pembelajaran yang telah dilakukan }\end{array}$ & 201,4 & Baik \\
\hline 4 & $\begin{array}{l}\text { Apakah dosen melakukan penyegaran dalam } \\
\text { proses pembelajaran di dalam kelas }\end{array}$ & 198,2 & Baik \\
\hline 5 & $\begin{array}{l}\text { Apakah dosen memberikan penguatan dalam } \\
\text { setiap proses pembelajaran }\end{array}$ & 195,6 & Baik \\
\hline 6 & $\begin{array}{l}\text { Apakah dosen menghargai usaha dan karya } \\
\text { mahasiswa }\end{array}$ & 224,6 & Baik \\
\hline 7 & $\begin{array}{l}\text { Apakah dosen melakukan evaluasi yang } \\
\text { berkesinambungan }\end{array}$ & 205,8 & Baik \\
\hline 8 & $\begin{array}{l}\text { Apakah dosen melakukan penilaian dalam } \\
\text { berbagai aspek kondisi atau keadaan } \\
\text { mahasiswa }\end{array}$ & 198,6 & Baik \\
\hline 9 & $\begin{array}{l}\text { Apakah dosen memberikan nilai secara objektif } \\
\text { dan adil dalam penilaian }\end{array}$ & 235,8 & Baik \\
\hline 10 & $\begin{array}{l}\text { Apakah dosen memberikan hasil pekerjaan } \\
\text { mahasiswa dalam membahasnya dalam setiap } \\
\text { pembelajaran. }\end{array}$ & 208,3 & Baik \\
\hline
\end{tabular}

Sumber: Diolah dari hasil olah data SPSS

Berdasarkan Tabel 9, rata-rata pencapaian skor total sebesar 209,83 yang termasuk dalam manajemen pembalajaran yang baik, sedangkan jika dilihat per indikator/ item pernyataan terlihat bahwa indikator/ item pernyataan semua mempunyai krikeria.

c) Penjamin Mutu

Berdasarkan pengolahan data dari jawaban responden tentang penjamin mutu, dan output SPSS, maka kriteria variabel penjamin mutu tertera pada Tabel 10.

Tabel 10. Tabel Distribusi Frekuensi Jawaban Responden Tentang Penjamin Mutu

\begin{tabular}{lccc}
\hline \multicolumn{1}{c}{ Kategori } & Interval & Frekuensi & Persentase \\
\hline Sangat Baik & $43,00-50,00$ & 2 & 8,33 \\
\hline Baik & $35,00-42,00$ & 5 & 20,83 \\
\hline Sedang & $27,00-34,00$ & 14 & 58,33 \\
\hline Kurang Baik & $18,00-26,00$ & 3 & 8,33 \\
\hline Tidak Baik & $10,00-17,00$ & 1 & 4,18 \\
\hline Jumlah & & 25 & 100 \\
\hline
\end{tabular}

Sumber: Data diolah dari Frekuensi output SPSS 


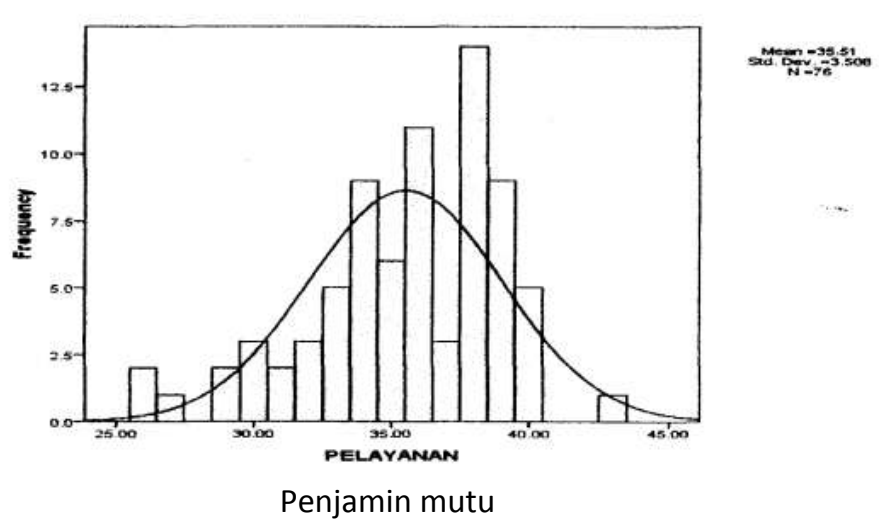

Gambar 3. Histogram dan Kurva Normal Penjamin Mutu

Berdasarkan Tabel 10, diperoleh jawaban 2 responden (8,33\%) penjamin mutu dalam kriteria sangat tinggi dan sebanyak 5 responden $(20,83 \%)$ menilai bahwa penjamin mutu dalam kriteria tinggi dan terdapat 14 responden $(58,33 \%)$ memberikan tanggapan penjamin mutu dengan kriteria sedang dan terdapat 2 responden $(8,33 \%)$ memberikan tanggapan penjamin mutu dengan kriteria rendah berjumlah 1 orang $(4,18 \%)$, dan pada histogram terlihat ratarata (Mean) score 35,51 dan standar deviasi 3,508.

Selanjutnya dapat digambarkan profil penjamin mutu per indikatornya/ item pernyataan dengan terlihat dahulu dengan menentukan interval score sebagai berikut:

Total Score Tertinggi $=24 \times 5=120$

Total Score Terendah $=25 \times 1=25$

$\mathrm{I}=\frac{\mathrm{NT}-\mathrm{NR}}{\mathrm{K}}$

$I=\frac{240-25}{5}=43,2$

Sehingga diperoleh interval skor sebagai berikut:

$24-66,2$ Tidak Baik

67,2 - 110,2 Kurang Baik

111,2 - 154,2 Sedang

155,2 - 198,2 Baik

193,2 - $240 \quad$ Sangat Baik 
Tabel 11. Tabel Profil Kriteria Manajemen Pembelajaran per Indikator/ltem Pernyataan

\begin{tabular}{clcc}
\hline No & \multicolumn{1}{c}{ Pernyataan } & Skor Total & Kriteria \\
\hline 1 & $\begin{array}{l}\text { Apakah mahasiswa merasa nyaman dengan } \\
\text { terbatasnya waktu proses pembelajaran }\end{array}$ & 194,5 & Baik \\
\hline 2 & $\begin{array}{l}\text { Apakah dosen memberikan kesempatan } \\
\text { dalam melakukan pengayaan dan perbaikan } \\
\text { nilai mahasiswa }\end{array}$ & 235,5 & Baik \\
\hline 3 & $\begin{array}{l}\text { Apakah dosen membangun hubungan antar } \\
\text { personal dengan mahasiswa }\end{array}$ & 201,4 & Baik \\
\hline 4 & $\begin{array}{l}\text { Apakah dosen memberikan sanksi apabila } \\
\text { terdapat mahasiswa yang tidak mengerjakan } \\
\text { tugas }\end{array}$ & 198,2 & Baik \\
\hline 5 & $\begin{array}{l}\text { Apakah anda mengenal semu dosen pasca } \\
\text { USBRJ }\end{array}$ & 195,6 & Baik \\
\hline 6 & $\begin{array}{l}\text { Apakah dosen anda sudah bekerja dengan } \\
\text { sesungguhnya }\end{array}$ & 224,6 & Baik \\
\hline 7 & $\begin{array}{l}\text { Apakah pelajaran yang diberikan oleh dosen } \\
\text { anda dapat anda terima }\end{array}$ & 205,8 & Baik \\
\hline 8 & $\begin{array}{l}\text { Apakah cara mengajar dosen anda sesuai } \\
\text { dengan keinginan anda }\end{array}$ & 198,6 & Baik \\
\hline 9 & $\begin{array}{l}\text { Apakah dosen senang dengan kondisi } \\
\text { mahasiswa yang ada }\end{array}$ & 235,8 & Baik \\
\hline 10 & $\begin{array}{l}\text { Apakah cara mengajar dosen anda sesuai } \\
\text { dengan ketentuan yang ada }\end{array}$ & 208,3 & Baik \\
\hline Sumber: Diolah dari hasil olah data SPSS &
\end{tabular}

Berdasarkan Tabel 11. terlihat bahwa rata-rata pencapaian score total sebesar 209,83 yang termasuk dalam prestasi yang baik, sedangkan jika dilihat per indikator/ item pernyataan terlihat bahwa indikator/ item pernyataan semua mempunyai krikeria baik.

\section{Analisis Regresi Linier Sederhana (Berganda)}

a) Pengaruh Kompetensi pedagogik terhadap Penjamin mutu

Berdasarkan data tentang tabulasi hasil penyebaran kuesioner dan regresi kompetensi pedagogik, dan penjamin mutu dapat dijabarkan analisis regresi tentang Pengaruh Kompetensi pedagogik dan Penjamin mutu sebagai berikut:

$$
\begin{aligned}
& =\frac{25(196.50)-(67)(68)}{25(196.50)-(67)^{2} \cdot\left(25(192,56)-(68)^{2}\right.} \\
& =\frac{4762.5-4556}{(4912.5-4489) \cdot(4812.5-4624)}
\end{aligned}
$$


$=\frac{206,5}{(423,5) \cdot(188,5)}$

$=\frac{206,5}{79829,75}=0,73086587821=0,731$

Dari hasil perhitungan di atas di dapatkan nilai 0,731, dengan demikian berarti pengaruh kompetensi pedagogik terhadap penjamin mutu ada pada kategori sedang, dengan demikian jika kompetensi pedagogik tinggi maka cenderung penjamin mutu juga akan semakin baik dengan peningkatan sebesar $50,2 \%$.

b) Pengaruh Manajemen Pembelajaran terhadap Penjamin Mutu

Berdasarkan data tentang tabulasi hasil penyebaran kuesioner dan regresi manajemen pembelajaran, dan penjamin mutu dapat dijabarkan analisis regresi tentang Pengaruh manajemen pembelajaran terhadap Penjamin mutu sebagai berikut:

$$
\begin{aligned}
& \frac{25 \cdot 6644(2419)-(67)}{\left.25(239321)-(2419)^{2}\right) \cdot\left(25 \cdot(196,50)(67)^{2}\right.} \\
& =\frac{163500-162073}{(5983025-585156) \cdot(4912,5-4489)} \\
& =\frac{1427}{11464 \cdot 423,5} \\
& =\frac{1427}{2203,41} \\
& =\frac{1427}{2203,41}=0,646458972=0,646
\end{aligned}
$$

Dari hasil perhitungan di atas diperoleh nilai 0,646 , dengan demikian berarti pengaruh manajemen pembelajaran terhadap penjamin mutu ada pada kategori cukup baik, dengan demikian jika manajemen pembelajaran tinggi maka cenderung penjamin mutu juga akan semakin baik dengan peningkatan sebesar $71,9 \%$.

Analisis Regresi Linier Berganda Pengaruh Kompetensi pedagogik dan Penjamin mutu terhadap Manajemen Pembelajaran

Berdasarkan pada hasil perhitungan rumus regresi linier berganda sebagaimana telah dikemukakan diatas, selanjutnya dimasukan ke dalam rumus regresi linier berganda sebagai berikut: 


$$
\begin{aligned}
& =\frac{25 \cdot(0,646)-(0,731)(0,683)}{\left(1-(0,731)^{2}\right)\left(1-(0,683)^{2}\right.} \\
& =\frac{16,15-0,499273}{(1-0,534)(1-0,466)} \\
& =\frac{15,651}{(0,466) \cdot(0,534)} \\
& =\frac{15,651}{0,248844} \\
& =62,893
\end{aligned}
$$

Dari hasil di atas diperoleh nilai koefisien korelasi sebesar 62,893 yang ternyata bebih besar dari table distribusi $f=4,8$ dengan demikian berarti terdapat pengaruh yang signifikan antara kompetensi pedagogik terhadap penjamin mutu pada Universitas Sang Bumi Ruwa Jurai. Kemudian pengaruh antara kompetensi pedagogik dan penjamin mutu dapat dijabarkan dalam rumus sebagai berikut:

$=\frac{25 \cdot(0,731)-(0,646)(0,683)}{\left(1-(0,646)^{2}\right)\left(1-(0,683)^{2}\right.}$

$=\frac{18,275-0,441}{(1-0,417)(1-0,466)}$

$=\frac{17,834}{(0,583) \cdot(0,534)}$

$=\frac{17,834}{0,311322}=57,28$

Dari hasil di atas didapatkan nilai koefisien korelasi sebesar 57,28 yang ternyata lebih besar dari tabel distribusi $f=4,8$ dengan demikian berarti terdapat pengaruh yang signifikan antara penjamin mutu terhadap manajemen Pembelajaran. Kemudian pengaruh antara penjamin mutu dengan manajemen pembelajaran dapat dijabarkan dalam rumus sebagai berikut:

$=6644-\frac{(2419)(67)}{25}$

$=6644-\frac{162073}{25}$

$=6644-6482,92=161,08$ 
$=6644-\frac{(2419)(68)}{25}$

$=6644-6579,68=64,32$

Dari hasil di atas diperoleh nilai koefisien korelasi sebesar 64,32 yang ternyata lebih besar dari tabel distribusi $f=4,8$ dengan demikian berarti terdapat pengaruh yang signifikan antara penjamin mutu terhadap manajemen pembelajaran di pasca sarjana Universitas Sang Bumi Ruwa Jurai Lampung.

\section{SIMPULAN}

Pengaruh kompetensi pedagogik terhadap penjamin mutu, dan berada pada hasil perhitungan 0,731 pada kategori cukup erat. Pengaruh penjamin mutu guru terhadap manajemen pembelajaran dan berada pada hasil perhitungan 0,646 pada kategori sedang. Ada pengaruh kompetensi pedagogik dan manajemen pembelajaran terhadap penjamin mutu di Universitas Sang Bumi Ruwa Jurai Lampung cukup baik dengan hasil regresi sebesar $\mathrm{Ya}=\mathrm{ax} 1+\mathrm{bx} 1$ $=19,477=22,762+21,69$, dengan demikian berarti terdapat pengaruh signifikan antara kompetensi pedagogik dan manajemen pembelajaran dosen terhadap penjamin mutu pada pasca sarjana Universitas Sang Bumi Ruwa Jurai Lampung.

Berdasarkan analisis dan pembahasan terhadap beberapa hal yang kondisinya belum baik atau belum optimal pada Universitas Sang Bumi Ruwa Jurai penulis memberikan saran ataupun masukan sebagai berikut:

Dosen selayaknya memiliki kompetensi pedagogik yang tinggi dalam upaya untuk meningkatkan pejamin mutu sehingga menjadi lebih baik dari sebelumnya. Dosen dapat lebih bervariatif lagi dalam menerapkan strategi pembelajaran yang sesuai dengan kondisi dan perubahan zaman yang berkembang. Dosen dapat memberikan beban tugas tambahan pada mahasiswa, karena, kurangnya beban tugas yang diberikan pada mahasiswa mendorong mahasiswa tidak kompetitif, dalam artian pihak dosen maupun lembaga terlalu toleransi pada mahasiswa, yang mengakibatkan mahasiswa menggampangkan segala hal yang berkaitan dengan proses pembelajaran.

Pihak lembaga pasca sarjana dalam membuat tim penjaminan mutu dilakukan secara independen sebagai bentuk pertanggung jawaban pada stake holder dan dapat memudahkan lembaga untuk segera melakukan akreditasi maupun evaluasi diri secara berkala dan lebih fokul dalam pengelolaannya. Pihak lembaga dapat lebih memaksimalkan kerja secara kemitraan dengan pihakpengguna layanan jasa pendidikan secara lebih optimal dan profesional. 


\section{REFERENSI}

Arikunto, S. (1993). Prosedur penelitian Suatu pendekatan Praktek. Jakarta: Rineka Cipta.

Cooper, D. R., \& Emory, C. W. (1995). Business Research Methods. Chicago: Richard D. Irwin, Inc.

Depdiknas. (2005). Peraturan Pemerintah Republik Indonesia Nomor 19 Tahun 2005 Tentang Standar Nasional Pendidikan. Jakarta: Depdiknas.

Ghozali, I. (2002). Pengaruh Religiositas, Terhadap Komitmen Organisasi, Keterlibatan Kerja, Kepuasan Kerja dan Produktivitas. Jurnal Bisnis dan Strategi, 9, 1-13.

Hadi, S. (1994). Metodologi Research, Jilid I. Yogyakarta: Andi.

Pidarta, M. (2004). Manajemen Pendidikan Indonesia. Jakarta: Rineka Cipta.

Robbins, S. P., \& Coulter, M. (1999). Manajemen Jilid 1. Edisi Indonesia. Jakarta: Prenhallindo.

Sallis, E. (2006). Total Quality Management im Education, terjemahan. Yogyakarta: IRCiSoD.

Sardiman, A. M. (2004). Interaksi dan Motivasi Belajar Mengajar Ed.1, Cet.II. Jakarta: Raja Grafindo Persada.

Suherman, A., \& Mahendra, A. (2001). Menuju Perkembangan Menyeluruh. Jakarta: Direktorat Jenderal Pendidikan Dasar Menengah Bekerjasama Dengan Direktorat Jenderal Olahraga.

Sugiono. (2010). Metode Penelitian Pendidikan, Bandung: Alfabeta.

Sumarsono, H. M. S. (2004). Metode Riset Sumber Daya Manusia. Yogyakarta: Graha Ilmu.

Syafaruddin. (2005). Manajemen Lembaga Pendidikan Islam. Jakarta: Ciputat Press.

Bush, T., \& Coleman, M. (2008). Manajemen Strategis Kepemimpinan Pendidikan. Yogyakarta: Ircisod.

Undang-Undang Guru dan Dosen no 14 Tahun 2005. 